\title{
European urban water crisis: the management dimension
}

\author{
Bernard BARRAQUE ${ }^{*}$, Laure ISNARD² ${ }^{2}$ Julien SOURIAU ${ }^{2}$ \\ ${ }^{1}$ CNRS-CIRED, Agroparistech, 19 avenue du Maine, 75732 Paris Cedex 15, France-bernard.barraque@agroparistech.fr \\ * corresponding author. \\ 2.Agroparistech, 19 avenue du Maine, 75732 Paris Cedex 15, France - laure.isnard@agroparistech.fr, julien.souriau@agroparistech.fr
}

\begin{abstract}
Between 2009 and 2013, the EAU\&3E research program gathered several French research teams and water utilities, with the aim to provide a scientific answer to the following question: are our water services sustainable, even in the heart of Europe? The goal of this project was develop knowledge and improve methods to achieve a sustainable management for water services. Our ambition was to go beyond the separate analysis of each dimension of sustainable development (economic, social, environmental): in parallel and together, we tried to add knowledge on 4 major dimensions (namely: environment, economics, equity and governance), applied to a set of empirical case studies in France and in other OECD countries. We specifically focused on: a) the recent decline in water consumption and its feedbacks with water tariffs and water utilities' financial balance; b) the long term asset management issue, related to the necessary renewal of aging water infrastructures; c) the redistributive effects, including growing water poverty due to counter-intuitive effects of water tariffs; d) the new territorial scaling options for water service management (up-scaling, downscaling, technology mix), including multi-level governance to improve the resilience of urban water supply and to foster the participation of water users. Lastly, we synthesized our findings in a set of scenarios on upcoming possibilities for future water service management in European cities. Forecasting offers many interesting tools to support water services authorities and operating companies in its decisions and to better apprehend the sustainable/unsustainable paths for its future. In this paper we focus on large cities in France (Paris) and Spain (Madrid and Barcelona).
\end{abstract}

Key-words: utilities, governance, sustainability, foresight, Paris-Madrid-Barcelona.

\section{Crise de l'eau urbaine en Europe, ou des modèles de sa gestion ?}

RÉSUMÉ. - Pendant 4 ans, le partenariat Eau\&3E (ANR) a étudié la durabilité des services d'eau dans les villes européennes, en travaillant simultanément sur les 3 dimensions classiques du développement durable, ou 3 «E» (économie, environnement, équité) plus la gouvernance territoriale. Le projet a démontré que si nombre de villes conduisent des programmes allant dans le sens de la durabilité de tel ou tel de ces axes, il est plus rare qu'elles en proposent une approche intégrée. Or à moyen terme les évolutions sur un de ces axes influencent les autres axes. Afin de mieux saisir ces interactions, nous avons essayé d'améliorer les connaissances sur l'évolution de la consommation d'eau, sur les bonnes pratiques de gestion à long terme du patrimoine technique, sur les effets redistributifs des changements tarifaires, et sur les nouvelles formes de gouvernance territoriale de l'eau. Ce travail a permis d'identifier les différents facteurs qui participent à l'émergence de crises de l'eau urbaine dans les villes européennes et de mettre en lumière les trajectoires engendrées sur le long terme par les différents modèles de gestion de l'eau. Pour illustrer cette méthodologie, nous l'appliquons ici à trois cas d'étude : les services public d'eau de Paris, Madrid et Barcelone. L'analyse de leur développement et de leurs crises sur le temps long permet d'observer que ces trois services d'eau se sont développés en privilégiant des solutions techniques toujours plus sophistiquées, notamment pour éviter d'aggraver certains conflits sur le territoire de la ressource dont elles dépendent, avec des spécificités pour chacun des 3 cas étudiés. Grâce à la méthode des $3 \mathrm{E}$ et à son application sur le temps long, nous avons pu montrer que le renforcement constant des capacités de production de ces services d'eau a eu des conséquences non anticipées par les gestionnaires. Par exemple, cette stratégie a conduit à une hausse chronique des investissements, puis des coûts d'opération ou de maintenance ; elle a contribué à l'épuisement des principales ressources en eau disponibles sur ces territoires; elle a des conséquences politiques pour les usagers du service comme pour ceux de la ressource en eau. De plus, la baisse continue de la consommation d'eau observée depuis les années 1990 remet en cause ce développement soutenu par la croissance, avec des conséquences diverses : Barcelone se retrouve avec une usine de dessalement d'eau de mer qui n'est plus indispensable, Paris réfléchit à mutualiser ses moyens de production, Madrid a été sauvée in extremis par la baisse des consommations. Enfin, la mise en évidence et la compréhension affinée des dynamiques et des tendances lourdes, passées ou présentes a servi de base au développement d'une analyse prospective du futur des services d'eau potable urbains. La co-construction de scénarios à horizon 2020 et 2050 a permis d'illustrer les contraintes imposées au système, mais aussi les marges de manœuvre et les grandes alternatives de décision stratégique sur lesquelles doivent se positionner les responsables des services d'eau, pour faire face à la crise de l'eau urbaine.

Mots-clés : service public d'eau, gouvernance, développement durable, prospective, Paris, Madrid, Barcelone. 


\section{INTRODUCTION: FROM SUCCESS TO CRISIS?}

On average, European metropolises run highly developed water services: the connection rate to centralized urban water systems is very high, due to both population density and historically massive but efficient investments. Indeed, average domestic water consumptions remain quite moderate $(150 \pm 50 \mathrm{lcd})$, compared to the USA, where average consumption is 2-3 times higher.

This success story is chiefly based on the matching of technology and institutions: water and sanitation systems, separated from the water resource by drinking water and waste water treatment plants on either side of water use, generated a model of public but commercial services. The progressive billing of the water service to its end users has been facilitated by the development of closing taps and water meters [Chatzis, 2006]. This technical model was usually associated with the involvement of local public authorities, which generally had legal competence over water services since mid $19^{\text {th }}$ century. Of course, upper levels of government played a role in the protection of water rights and in the organization of natural monopolies, as well as with both direct and indirect funding (public grants, guaranteed city bonds, etc.). But until wastewater collection and treatment were added to drinking water bills, and underwent increasingly severe discharge standards, urban water utilities were able to develop a good self-financing capacity [Crespi-Reghizzi, 2014].

Unfortunately, since the 1980s this model has been confronted to a growing and unprecedented crisis, which may lead to unsustainability in the future. First, the transfer of the costs of sewerage on the water bill is causing a dramatic increase of the average water charge to be paid by the end users. In addition, aging water infrastructure needs to be renewed but without the public subsidies available for initial installations. And this, at the very same moment the European Union urges member States to improve the environmental and public health performances of their water utilities. Typically, the cumulated cost of the Urban Waste Water Directive (EC 91/271), for the 15 member states of the EU, was estimated at $€ 150$ billion! These various causes resulted in a rapid increase of the water bills: in France for instance, the average water bill has been multiplied by 2 to 3 times since 1990 , from $€ 1,5 / \mathrm{m}^{3}$ to $€ 3,6 / \mathrm{m}^{3}$ in 2008 .

Second and paradoxically worse: water price increases have slowly triggered a contraction of the water demand in European metropolises, due to (long term) price elasticity of demand [Barraqué, et al., 2011] but also to growing environmental awareness of the users, as well as to lower affordability of water for the low income groups. In most European cities, cost recovery based on volumes sold turns any reduction of water consumption into a loss of revenues for the water utility. The latter is frequently bound to increase water tariffs to balance its expenditures with revenues. This evolution will foster an additional drop of the water demand, etc.

Third, growing water rates generate problems of water affordability for the poor. Since the seminal study of Fitch $\&$ Price [Fitch, Price, 2002], households paying more than $3 \%$ of their revenues to access WSS services are considered "water poor". This is quite a paradox: European metropolises have continuously improved their water services, but they are now experiencing growing water poverty concerns, which were supposed to concern developing countries only.

All these combined factors have generated a new uncertainty and complexity for water services management, and improving the performance on any of the 3 dimensions of sustainable development (the three E's: Environment, Economics, Equity) may result in some unexpected or unwanted consequences on other dimensions. In addition the Water Framework Directive requests to derive water policies from the recovery of the aquatic environment's quality, which ultimately leads water and sanitation utilities to get involved in water resources management: they look for territorial solutions and ecosystems services approaches as a cheaper and better alternative to the pursuance of technology sophistication. Facing the deteriorating global situation, most utilities try to improve their service by dealing with the most urgent problem. But this management model seems to increase the difficulties in one of the other dimensions of the service's development. In addition, it usually does not face the new issue of climate change.

For this reason, our ambition is to reach a better understanding and assessment of water services sustainability, beyond the usually separated discussion of economic, social or environmental issues. In this paper, we present the methodology we developed in the EAU\&3E research project to get an integrative approach of the European water services management. Then, we will apply this methodology to three cases: the cities of Paris, Madrid and Barcelona. Last, we show the importance of conducting foresight studies, as they can highlight the main challenges that the European water utilities will face in the coming decades and may help us to answer the question: will water services be sustainable in 2050, even in the heart of Europe?

\section{ASSESSING WSS SUSTAINABILITY THROUGH A LONG-TERM INTEGRATIVE APPROACH: THE EAU\&3E PROJECT}

The study of sustainability of water services in European cities was initiated in 1999 by the WATER 21 research project, funded by the European Union and co-ordinated by Pr. Francisco Nunes Correia of Lisbon Technical University. Already, the project concluded to the necessity to take into account simultaneously the 3 dimensions of the sustainable development. But it appeared to some French researchers that a diachronic approach, based on a long-term study of the water service, was necessary to achieve a relevant assessment of these utilities' sustainability.

Thus in 2009 a research program on sustainable cities developed by the French Research Agency (ANR), provided significant funding for EAU\&3E, a 4-year research project on water service sustainability management (http:// eau3e.hypotheses.org). This project gathered 6 research teams providing jointly the needed qualification to address the different issues relating to water services sustainability $^{1}$. Our partnership involved a larger academic network, which allowed gathering examples drawn from many cities and countries. The EAU\&3E project also supported partnerships with several water utilities and local water authorities in France, in particular Paris (with Paris public water supply: Eau de Paris), Bordeaux (with the mixed joint board between Bordeaux metropolitan authority and the Gironde County: SMEGREG), with water utilities in Mediterranean cities of Montpellier and Perpignan (cf. researchers from BRGM and IRSTEA) and in Nantes and Rennes (researchers

1. CIRED-CNRS (Paris), Geste-IRSTEA (Strasbourg), BRGM économie (Montpellier) UMR G-Eau - IRSTEA (Montpellier), Agroparistech-ENGREF (Montpellier) ADES-Université Montaigne (Bordeaux), plus the consulting firm Cogite acting as a subcontractor to the project (Castelnaudary). 
from ENGEES-Strasbourg). These partnerships facilitated our access to ground information and to very practical sustainability issues, each of these water services partners facing different sustainability issues (cf. infra).

We tried to jointly consider the 3 above-mentioned dimensions of sustainable development (i.e. the 3 E's) plus a fourth dimension: governance. We related this last dimension with the interactions between elected authorities, technical operators and the users (internal governance), and with territorial rescaling or multi-level interactions (external governance). Doing so we considered the impacts of governance on the resilience of the water service as well as on the participation of the many water service stakeholders. We discussed the advantages and drawbacks of several re-scaling options for both the technical and institutional territories of the water services (up-scaling, down-scaling, together with adaptation of the technology mix). On the one hand, we conducted a survey in Europe, the USA and Australia on the pooling of financing, of production of drinking water, and wastewater treatment. In France, we studied various arrangements between the départements, the metropolitan areas and other new territorial reform projects, challenging the current scaling of water services. But we also studied the potential downscaling of the existing water service's territories through decentralized technologies (e.g. eco-districts), in particular for low density peripheries. Our goal was to find how a better match between technical and institutional territories could achieve positive benefits on the long run, and to improve the participation of citizens-water users.

As a result we were able to bring additional knowledge in each of the four dimensions of the water services sustainability, but also to develop a methodology easy to understand and to replicate. We also clearly highlight the necessity to consider the management models in the past, as it is the only way to point up some non-sustainable evolutions. In the following section, we try to apply the EAU\&3E method to three cas studies, in order to illustrate these results.

\section{PARIS, MADRID AND BARCELONA: TECHNOLOGY VS SUSTAINABILITY?}

Paris, Madrid and Barcelona are now quite large urban areas; they have developed their water infrastructure since the $19^{\text {th }}$ century and are, to some point, perceived as exemplary in the way they deal with their utility. Thus, they are interesting case studies to apply a long-term sustainability analysis. Here we focus on water supply.

\section{III.1. Paris}

In Paris, modern water and sanitation service was launched in the second half of the 19th century by Prefect Haussmann. When he was appointed by the Emperor at the head of the Seine County, there was already a water system in Paris, but it was chiefly used for street and drainage system cleaning, parks watering, fire fighting; it was only marginally utilized to supply water to public fountains. At that time, several private ventures were delivering piped water to some neighborhoods or monasteries, while most of the population had wells or bought its water directly from street vendors.

In 1853, the year when Prefect Haussmann was appointed, was also created the Compagnie Generale des Eaux (CGE), a private water company which was already getting control over water services in most Paris' suburbs. Haussmann decided for a public monopoly of both public and private water supplies. However, he decided to pact with the CGE: he maintained the "public" water service free to supply water to fountains and for collective uses, while a "private service" was unified, with water produced by Paris public administration but sold and later metered to wealthy private customers by the CGE. This arrangement lasted more or less unchanged until 1984. It had the advantage to ensure free access for all to public fountains in a city well known for its revolutionary background, but also to incentivate the susbscription and connection of households and commerce to the better quality and pressurized, but paying "private" water system.

Initially, the drinking water (i.e. 'private') service was fed with distant water captured from clean springs far from the capital and carried to Paris by massive aqueducts; yet at the end of $19^{\text {th }}$ century, these aqueducts proved to be insufficient and additional water was pumped from the Seine river in a filtration plant just upstream Paris (Ivry), following the example of London water system [Barraqué et al., 2015]. Soon, chemical treatments were invented and used, allowing this surface water to be a viable solution both in terms of public health and financing. Today the 20 arrondissements of Paris receive half of their water from distant water sources, the rest being taken from nearby rivers and treated in water plants. In Paris' suburbs, a very large joint board gathered more than 140 municipalities, run by the CGE through a management contract, to supply surface water from three treatment plants on the Seine, Marne and Oise rivers. But there are other joint boards and isolated communes operating their own water systems in the Paris' metropolitan area, with other water authorities, operators (e.g. Lyonnaise), and their own water supply systems. In the end, Paris metropolis densest area (8 million inh.) receives water from no less than 15 water treatment plants, via networks which were only interconnected after the 1976 drought episode [Souriau, 2014]. In comparison, waste water is treated at upper territorial scales. Obviously, a consolidation of all these water systems (and thus a lower number of water plants) would make sense. This issue was opened after Paris council decided in the 2000s to reclaim the public management of its water service, opening a debate on creating a metropolis level joint board to produce water for all the metropolitan area.

Meanwhile, in the city of Paris and the inner suburbs a marked water consumption decline is observed. In Paris alone, since 1990 the water consumption has dropped by $30 \%$, yet in absence of any large water conservation campaign. In such conditions, the water utility experiences difficulties to match decreasing revenues with continuously rising production costs; this rise is due to the need to renew and upgrade the existing water infrastructure, as well as to comply with stricter environment and public health standards. As a consequence, in order to balance the expenses by new incomes, the municipality had to increase the water rates in 2007 even though the Mayor had promised to reduce them!

In addition, partly for following and controlling consumption decline, and partly to develop a new relationship with customers, Paris installed smart water meters. In 2009 Paris also decided to close one of its drinking water plants: the historical filtration site in Ivry had become redundant. Yet it had been modernized with top treatment technologies in 1994 and 2005. Paris water service is also struggling to protect its distant water catchments, which may require to buy land or to compensate local farmers for adopting less polluting practices (e.g. organic agriculture). The development of the non-potable water supply system at the level of the whole region is also considered as a way to find a new balance with the water resources in order to face a situation 


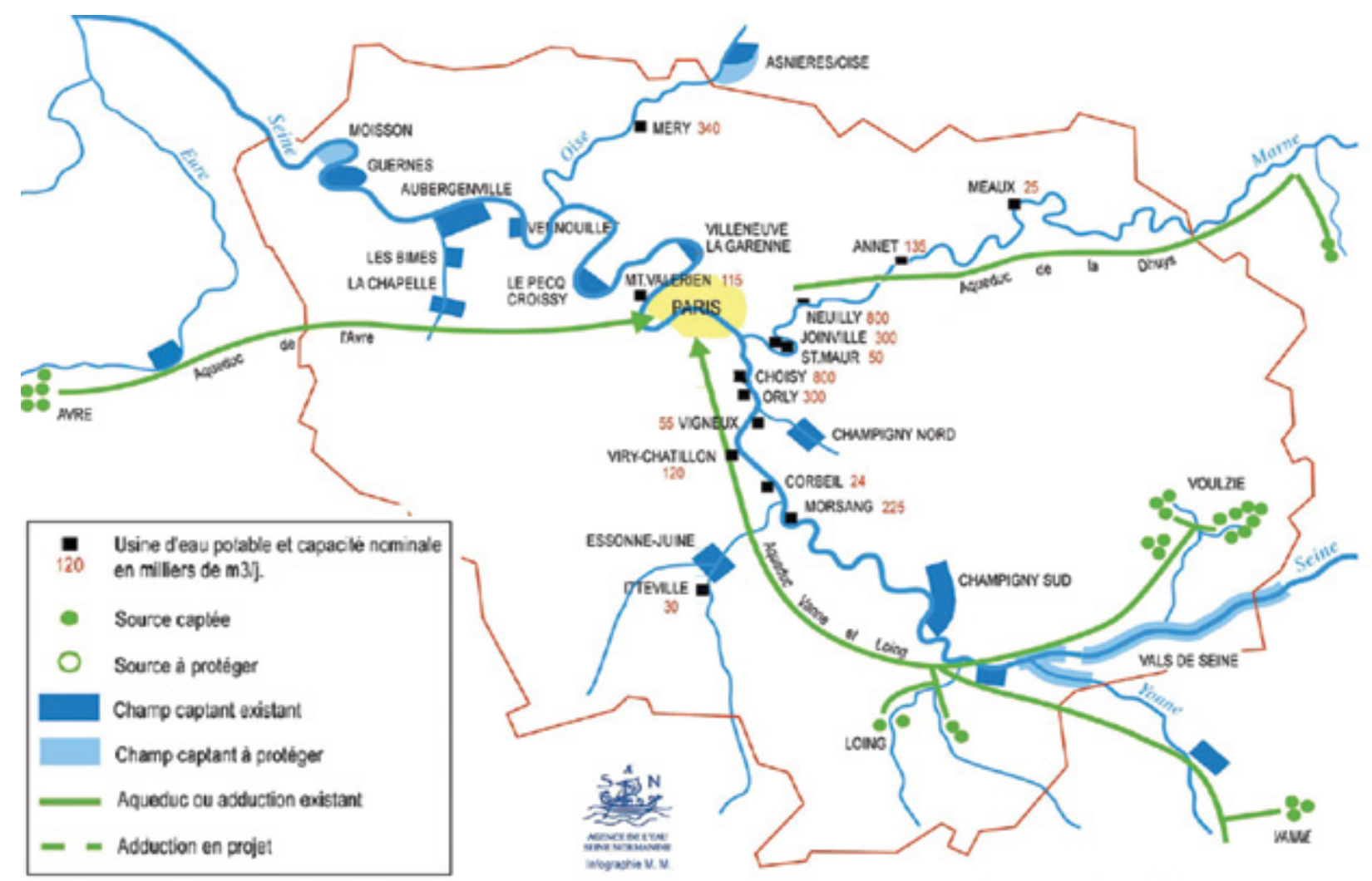

Figure 1 : The Water supply system in Paris. Source: Agence de l'Eau Seine Normandie.

of relative scarcity [APUR, 2011]. Paris thus illustrates how European cities face the choice between sophistication of technology and territorial governance improvements. Until now, no economic study has been made of the additional problems due to climate change in the area of water, but the city's climate plan considers the event of prolonged droughts in autumn, and heat waves in the summer.

\section{III.2. Madrid}

The capital city of Spain is surrounded by a federal district: its $8.000 \mathrm{~km}^{2}$ wide territory is occupied by 6.5 million inhabitants. Due to the semi-arid mediterranean climate, and despite the presence of rain-catching mountains north and west of the district, this territory long suffered water scarcity problems. In the middle of $19^{\text {th }}$ century, a central government policy acted to build aqueducts and dams, so as to eventually supply sufficient quantities of water to the whole Madrid community, via a performing public company. One can draw a parallel with Paris: in both capital cities the initial project was to create a supra-local public institution to supply water to more than the central municipality, i.e. to the whole county (cf. the Seine département and Paris). This project was maintained in Madrid but was abandoned in Paris due to the rise of municipal powers at the end of $19^{\text {th }}$ century [Souriau, 2014: 288].

However, in both cases long distance aqueducts were developed till after WWII. A few years before Paris, the Spanish national government built a long distance aqueduct: Canal Isabel II, called after the Queen's name, was able to divert from river Lozoya twice more water than the demand at the time. The project was adopted in 1848 , and water reached the city 10 years later. During the following decades, additional water resources were captured, and reservoirs were built around the metropolis. In particular, Canal Isabel II bought back a company holding a hydro-electric concession, but which had to supply water to some users under a former contract. This company fought to obtain the right to serve water to the upper areas of some suburbs of Madrid, but the Manzanares river where water was abstracted was of poor quality. After a struggle which lasted about 60 years, Canal Isabel could buy the stock of this company and finally reached a monopoly situation in the $1960 \mathrm{~s}$. At the beginning of the $21^{\text {st }}$ century, Canal Isabel II even formed a joint venture with Hidroelectrica del Cantabrico, allowing both companies to support each other financially, heading toward a form of multiservice/multi-territorial semi-public management formula.

Since 1977 Madrid public water company is no more run directly by the State but has its own budget and legal standing. The new entity is responsible for WSS of 6.3 million inhabitants in most of the Madrid district. Its typical consolidation at supra-local level allows bridging WSS services and water resources management, thus improving Madrid's resilience vz climate change uncertainties. But the size of the metropolis, in the face of the limited flow of the local rivers remains a serious problem: in order to cope with increasing population and activities, Canal Isabel II had to continuously look for new additional water resources. After its 14 reservoir sites were exploited and dams capacity was fully used, Madrid started to drill for additional groundwater. However, this resource appears insufficient and too fragile to ensure a continuous water supply for Madrid metropolis. Alternatively, Madrid decided to build a Reverse Osmosis filtration plant on the main nearby river, but the resource was already used by other utilities and is also required to maintain biodiversity. 


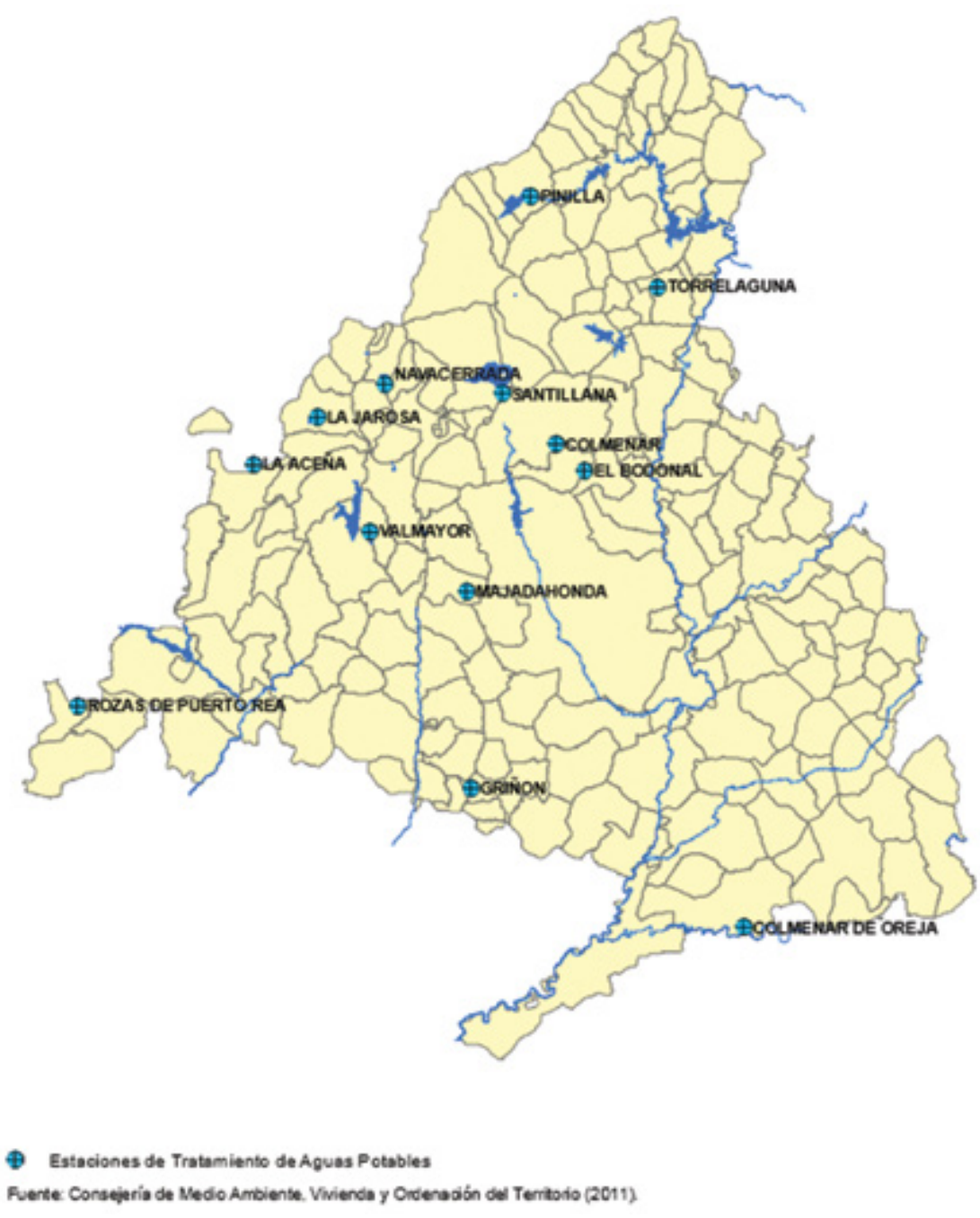

Figure 2 : Location of the water treatment plants in Madrid Province. Source: Spanish Ministry for the Environment (2011).

In the $2000 \mathrm{~s}$, the situation became quite tense when successive serious droughts increased the water demand while the reservoirs were almost empty [Souriau, 2014: 266-267]. Neither the decision to strongly increase the water rates nor the awareness campaign or the water conservation measures were sufficient to cover the water demand with the existing water supply capacities. At last, awareness of the water users and economic recession led to a demand reduction ${ }^{2}$, so the water system came back to a more balanced situation (for partly unexpected causes). Another unexpected outcome is that like Paris, Madrid has now developed a dual water supply system: local treatment plants reclaim wastewater, in order to water public parks, to clean streets and to supply water to local industries. But while peak demand in drought period is now a risk under control, the drop of water consumption and the need to renew and upgrade the ever costlier WSS infrastructure in the present economic crisis brings a new issue: the local government of Madrid favors an increase water rates and privatization of Canal Isabel II to get more funding, even though neither option seems able to change the parallel rise of costs and rates, given the concerns on future water resources scarcity under Climate change.

2. Total water billed went down from 240 to $180 \mathrm{Litres} /$ cap/day between 2002 anf 2012.

\section{III.3. Barcelona}

Barcelona is another interesting case. It is the largest harbour on the Mediterranean coasts; when the "movida" took place after Franco's death and Spain returned to a constitutional monarchy, the head city of Catalonia was convinced that its population and activity would grow so fast that it would soon lack water, as in the previous decades.

Back in 1924, the municipality authorized a company with initial Belgian capital, later named Aguas de Barcelona or AGBAR, to supply water that was pumped in the Llobregat in the suburbs of the city [Sauri, et al., 2014]. The main problem is that the river was becoming one of the most polluted in Spain, due to industrial expansion in the area. In particular, this water had a salt content and taste, due to abandoned salt mines on a tributary of the Llobregat. But, apart from local wells of minor importance, it remained the only source of water during most of the authoritarian regime. Then dams were built upstream to better regulate the river flow, and at the end of the 1950's it was decided to get water from the Ter, a river in the neighboring basin in the north. The $100 \mathrm{~km}$ transfer was operational in 1966.

The return to a democratic regime allowed the Catalan Region Government to recover its authority on the water policy in the eastern part of its territory (the west being a part of the inter-regional basin of the Ebro river). In 1991, 


\section{El agua de Barcelona}

\section{Configuración del sistema hídrico en el entorno} del área metropolitana de Barcelona

\section{EMBALSES}

ZONA DE CAPTACION DE AGUA DE LLUVIA

CANALIZACION

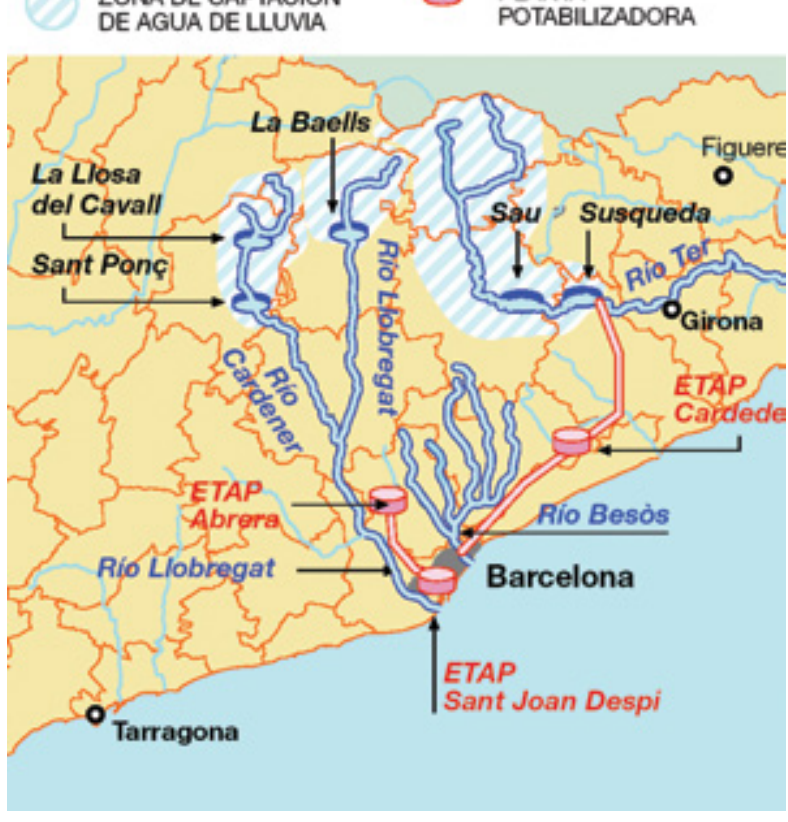

Figure 3 : Water in Barcelona. Organisation of the water supply system for Barcelona's metropolitan area. Source: David Sauri (2012).

Catalonia set up a public regional bulk water company, ATLL (Aguas Ter Llobergat) to increase the volumes of water for the expanding metropolis and rationalize the system (typical up-scaling move). In the wake of the Olympic games of 1992, Barcelona fancied a rapid development which would increase population by $25 \%$ (from 4 to 5 million). Fearing to be short of water, the city claimed its need for water from further sources: it was considered to use the existing aqueduct bringing water from the Ebro delta to Tarragona, where petrochemical industry had developed, and to extend it another $100 \mathrm{~km}$ east to Barcelona. But the environmental movement, and donor regions like Aragon voiced against what they saw as a predation form a rich area. In the middle of the 1990's, Barcelona and Catalonia together imagined they could escape this political constraint thanks to an extension of the Rhone aqueduct, already serving the Montpellier area in France, all the way to Barcelona. However, it was readily shown that the expected population increase was not taking place and that per capita consumption was rather on the decline, so Barcelona would need additional water only in exceptional drought years (as occurred in 2008), and in much smaller quantities than planned.

Then Barcelona seized the opportunity of an important policy change which took place in 2004: the European Commission was about to stop funding the Spanish national water policy, on the grounds that the PHN (Plan Hidrologico Nacional) adopted under Prime Minister Aznar, was not based on sufficient economic and environmental impact analyses. Zapatero, the new Premier, announced the end of the $\mathrm{PHN}$ and its replacement by a series of desalination plants. Barcelona signed a BOT contract with AGBAR to build a large plant finally inaugurated in July 2009, just after an exceptional drought ended. This critical drought had forced the city to ship some water from Marseille and Tarragona. The very high cost of water transportation by tankers, made the desal plant welcome; but its quite high operational costs led the city to adopt two more innovations: (i) recovering stormwater in underground storage tanks, and re-use it for street cleaning and parks watering; (ii) building another treatment plant with the same membrane technology as the desal plant, but to treat grey water issued from the sewage treatment plant, and to recharge the river upstream the city.

In conclusion, Barcelona metropolitan area has reversed a traditional supply side and quantitative policy, which led to fetch water from increasingly distant territories, and instead chose local solutions based on non-conventional resources, tending to "close the small water cycle". On the institutional side, these non conventional choices allow the city and its private water supplier, to re-gain partial autonomy from the regional bulk water company supported by the Catalan region, even though it will still rely on its water. But they also make the desalination plant quasi-superfluous: it is already idle most of the time. Potential climate change is not changing this agenda much. In any case it might require a demand-side approach, but primarily targeting the very high consumption of rich neighborhoods in the outer periphery, like is being done in California, where climate change seems to hit hard on a Mediterranean climate.

These three case studies illustrate how a constant reinforcement of the water supply capacities may have unexpected consequences on the utility management. In the short term, this policy seems to be sustainable, since most innovations are based on technology sophistication, and do not modify in any way the water supply and sanitation relationship with the water users/customers. But on the longer run, a steady increase of the investments and of operational costs, a depletion of the water resources available on the territory, some major political changes, etc., should question how far this policy is sustainable.

\section{SCENARIOS FOR TOMORROW: AN OPERATIONAL APPROACH FOR FUTURE WATER SERVICES MANAGEMENT}

In the EAU\&3E project, we designed a set of scenarios, i.e. as many "possible pictures" of the future for water systems in 2050 , each framed by a coherent logic. Scenarios are useful to apprehend potential upcoming events, to compare the coherence or credibility of different proposals, and to clarify the motivations of the stakeholders. Furthermore, foresight provides scientific-based knowledge on possibilities, a frame to make the stakeholders discuss the desirable/ non-desirable consequences of their choices, the configurations to be promoted or avoided, and even a hint at which stakeholders would benefit or suffer most from each possible outcome.Thanks to these scenarios, we highlighted four main parameters to position water services towards sustainability (or not).

\section{IV.1. How to maintain financial balance, without exiting this management paradigm?}

In 3 scenarios, we assumed that in the future, water service management would stick to a strict application of the "water pays water" paradigm. Most technical, environmental and sanitary choices that have been adopted during past 
decades would then continue to be supported by the service beneficiaries. Yet, maintaining this status quo may rapidly prove to be a disaster for the water service sustainability, as the continuing fast increase of the average water bill will become unaffordable for a widening segment of the population, while the other water service conditions will continue to get more and more difficult to sustain.

Thus, new technical and management options will be promoted, such as new water pricing schemes (e.g. increasing blocks or seasonal tariffs), smart water meters for all water users, increasing public subsidies to limit unpaid water bills, support to alternative water techniques instead of investing in the public water network, etc. However, these solutions won't necessarily improve the existing water service's sustainability. On the contrary, such a strategy might lean the water service policy toward a growing technical and regulatory control of the water demand, causing debatable consequences on social and financial acceptability, or on the future environmental carrying capacity related to the water service.

\section{IV.2. Finding new financing modes for the service, or challenging the unique dimension of the service: at what cost?}

In the next scenarios, we assumed that water services will experience major evolutions in the future so as to overcome economic, social and environmental crisis. As a first option, new financing strategies will be explored as alternatives to the "water pays water" principle. For example, removing sanitation or waste water treatment, or firefighting water consumptions and costs, from water bills, or pooling the means of production and origin of water resources between neighboring utilities, may help to reduce water costs and prices. In such a case, institutional reshuffling and multi-utility companies could be considered as alternatives, which would require a deep cultural shift toward the Dutch, German or Swiss models of local public services management.

An alternative scenario would be to challenge the "equal service for all" paradigm. Public water service would become a "low cost" but universal water service, while a "premium water service" with higher quality would be proposed but affordable only to users with higher incomes (e.g. rich households, companies, administrations). This is by the way a frequent situation in developing countries, and even in Eastern Europe.

Both scenarios above would improve the financial balance of future water service. Yet, potential consequences raise questions on their political feasibility, and on the desirability of the decisions to be taken to achieve such future plans.

\section{IV.3. Territorial re-scaling: why the question of territories is not an expendable variable}

Three additional scenarios were forged to discuss the future scale of water production and supply. These scenarios considered both the territorial up-scaling of water supply - water resource interaction and of technical infrastructure, and the down-scaling of water services to become partly autonomous systems, at individual or eco-neighborhoods levels. In the first case, several neighboring water services would merge into one single larger utility, as a way to achieve economies of scale, rationalized water production, and higher territorial solidarity. At a more local level, we can imagine a city will negotiate with other local authorities and other nearby water suppliers, so they can ensure a more efficient use of the financial, technical or natural pool of resources.
In the second case, future water services will look for technical-based isolationism: the cities will ensure they become virtually autonomous from the variability of the surrounding water resources, using technical solutions such as rainwater harvesting, waste water recycling and reuse, etc. This is indeed studied by colleagues in the German Institute of Town Planning (DIFU). Ideally, the city water service would no more depend on the neighboring systems or on water resources. But such a solution won't stop the problem of global water resource quality worsening, nor the rise of services' production costs. In fact, down-scaling or decentralized solutions may also have adverse consequences that could contribute to deepening the crisis of water services. For instance, media coverage on rising water prices and autonomous water devices technologies (private borewells, recycling or reusing water systems, rainwater harvesting) have contributed to a new trend among users or groups of users, who decided to exit the public water network. While these options would definitely lower their total water consumption through re-use of their own water, on the other hand this double offensive/defensive against the centralized water service will reduce the incomes of the public service, thus increase the need for a renewed interaction between the city water service and the water users. Yet, is the participation of citizens to the water service a gain or a loss of time and means? What transaction costs or additional later costs will be spared ? What would be the consequence of more decentralized sociotechnical water systems at the user and city level? In the end, despite increasing transparency and responsiveness, the water utility does not necessarily come with a strong political vision: here again, the importance of political responsibility in water service management and in common goods regulation appears to be inescapable.

\section{IV.4. Governance as the main driver for action towards sustainability}

From a national worshop, where various stakeholders from the French water services sector gathered, we drew the lesson that, once more, governance appears to be the key element for any strategic reflections on what actions are to be taken for a sustainable water service in the future. Indeed, the question related to the "proper scale" for water service management appears to be central, but of lower interest compared with the essential role of the relationship established between the water service and its environment in a very broad sense: i.e. the associated sanitation service, hinterland territories, water resources, agriculture activities, hydro-electrical power production, as well as citizens acceptability, urban development and housing policies, or climate change. Therefore, the list of stakeholders to be involved in water service management may need to be expanded so a better representation and a wider scope of solidarity among interrelated water service stakeholders will be reachable in the future.

This point is critical since the 2000's Water Framework Directive of the European Union imposes deriving water management policies from the recovery of the aquatic environment's good status and water resources quality before the end of the decade, and thus pushes water services to interfere with the territories from where the water resource is captured. In most cases, this territory is regional or watershed-based, in any case broader than the territory covered by the water utility. Hence, water service authorities will have to invent new forms of governance - in this case, of multi-level governance - if they wish to maintain the urban water management development of European cities in its current configuration and level. 


\section{CONCLUSIONS}

Water services in European cities are highly developed. But are they sustainable? The study of economic, social and environmental issues at stake provides interesting information to plan innovative answers, but frequently avoids to consider how these 3 dimensions of sustainability are interacting. Yet they interact in sometimes quite unexpected ways: various loopholes and feedbacks, which tend to convert sector-specific solutions into unsustainable or worsening situations in the future.

Our ambition was to reach a better understanding of water service management and issues: we developed a more integrated analysis of combined sustainability stakes, in order to propose a more global futures' outlook. During a 4-yr long research project financed by the French Research Agency, the partners of EAU\&3E built a comprehensive analysis, based on mirroring French urban water services with European and American counterparts. We specifically addressed critical issues such as the interaction between water consumption decline and water tariffs evolution, the challenges of asset management opposing short term and long term issues, the social and economic impacts of tariff evolution on users (and among them on the low income groups) as well as on the budget of the water utility, and lastly governance issues related with re-scaling of institutional or technical water services' territories, and with multi-level governance and stakeholders' participation to WSS management.

The three case studies - Paris, Madrid and Barcelona water supply services - allowed us to prove that unsustainability can come out of internal management problems, and not only with increased water scarcity and climate change; and as a matter of fact, Paris and Madrid have not yet developed a detailed analysis of climate change economic impacts. They have a climate plan which is based on the hypothesis of prolonged and more extreme droughts, but this plan is not quantified in terms of budget. Barcelona seems to have a better plan, and it was probably triggered by the exceptional drought suffered in 2008. AGBAR, the water supply company of the central part of the metropolitan area, built its desalination plant to increase its resilience vz scarcities. Desalination and waste water re-use can be presented now as a reply to climate change, but in fact they were scheduled before the drought, and it is difficult to consider its costs as only CC-related.

This calls a more general reflection: a bibliography survey shows that cities have made economic analyses of CC impacts and of adaptation costs, only in the last 7 years, and after they experienced a dramatic episode of 'too much water': unusual heavy rainfall, hurricane, sea surge. In particular, coastal cities are sometimes able to calculate increased impacts of extreme events on top of slow and steady long-run sea rise. Some of them also design an adaptation plan assorted with an economic evaluation. Conversely, there is quasi no literature on cities deriving an analysis of CC impacts from an episode of extreme drought (e.g. Californian cities, or Saõ Paulo). The study of 4 large coastal cities by a French consortium funded by the World Bank and the French CDC, "Climate Change Adaptation and Natural Disasters Preparedness in the Coastal Cities of North Africa," presents a good assessment of damages in case of disasters due to the sea, the rain and earthquakes, and also offers a benefit-cost analysis of various adaptation measures. But the problem of lacking water resources is considered a minor one in relation with climate change (see for instance Ennesser, 2013). In any case, uncertainties in the climate change adaptation economic models are so important that most cities, including Mediterranean ones, will usually adapt their water policy agenda only marginally for climate change risks.

Meanwhile, the European well-developed water services might, by 2050 or even sooner, face a crisis of their management models. Designing scenarios appeared as a relevant way to identify the impact of past and present strategic choices on water services sustainability. It also allowed us to propose some solutions which might help avoiding a real water crisis in Europe by 2050. New water pricing schemes based on smart meters, adopt a more flexible approach of the "water pays water" principle, improve the social acceptability and desirability of the water services, or develop a relevant and strong multi-level governance should find their way on every water service manager's Agenda.

\section{ACKNOWLEDGEMENTS}

The authors wish to thank the French National Research Agency for the funding of the EAU\&3E project and all of their colleagues who took part into this 4-year project.

\section{REFERENCES}

Apur (Atelier Parisien D'Urbanisme) (2011) — Étude sur le devenir du réseau d'eau non potable. Partie 2 : Rappel et nouvelles pistes de réflexions sur le devenir du réseau d'ENP107p. Online http://www.apur.org/etude/etude-devenirreseau-eau-non-potable-partie-2-rappel-nouvelles-pistesreflexions

Barraque B., Isnard L., Montginoul M., Rinaudo J.D., Souriau J. (2011) - Baisse des consommations d'eau potable et développement durable. Responsabilité \& Environnement (série des Annales des Mines) 63 102-108

Barraque B., ISNARd L., Souriau J. (2015) - How Water Services Manage Territories and Technologies: History and Current Trends in Developed Countries. In Grafton $Q$ Daniell K.A., Nauges C., Rinaudo J.-D., Chan N.W.W.; (Eds.) Understanding and managing Urban Water in Transition, Springer 33-59

Chatzis K. (2006) - Brève histoire des compteurs d'eau à Paris, 1880-1930. Terrains \& travaux (ENS-Cachan) (2)11 159-178

Crespi Reghizzi O. (2014) — Providing a municipal infrastructure: how did Paris and Milan finance their water and sanitation infrastructure (1853-1925)? Flux (4) 97-98 44-59

ENNESSER Y. \& AL. (2013) — Etude sur la vulnérabilité et l'adaptation de la Wilaya d'Alger au changement climatique et aux risques naturels; Phase 2 : élaboration de plans d'action. Egis-Eau-IAU-BRGM report for the Algerian government and Caisse des Dépôts et Consignations 306p - http://beta.cmimarseille.org/sites/default/files/Brochure_ACC_Alger_0.pdf

Fitch M., Price H. (2002) - Water poverty in England and Wales. Report for the Chartered Institute of Environmental Health, published by the Public Utility Access Forum 45 p.

Sauri D., March. H., Gorostiza S. (2014) - Des ressources conventionnelles aux ressources non-conventionnelles : 1'approvisionnement moderne en eau de la Ville de Barcelone. Flux 97/98 101-109

SOURIAU J. (2014) - Stratégies durables pour un service public d'eau à Paris : Analyser et gérer les politiques d'hier, d'aujourd'hui et de demain. Doctoral thesis, under the direction of B. BARRAQUE, defended Nov. 4 2014. Agroparistech, Ecole doctorale ABIES, CIRED. 